\title{
Türkçe Öğretmeni Adaylarının Akıllı Telefon Kullanma Öz-Yeterliklerinin İncelenmesi
}

\author{
Fatih KANA ab, Hulusi GEÇGELc, Büşra ERGUNd ${ }^{\text {, }}$, Aysu GÜZEL ${ }^{\mathrm{e}}$
}

\section{Özet}

$\mathrm{Bu}$ araştırmanın amacı Türkçe öğretmeni adaylarının akıllı telefon kullanma öz-yeterlik düzeylerini belirlemektir. Bu amaç doğrultusunda araştırmada karma araştırma modeli kullanılmıştır. Araştırmanın örneklem grubunu Türkiye' nin batısında yer alan bir devlet üniversitesinde öğrenim gören Türkçe öğretmeni adayları oluşturmaktadır. Araştırmanın veri analizinde Aktay (2018) tarafından geçerliği ve güvenirliği yapılmış “Akıllı Telefon Öz- yeterlik Ölçeği" kullanılmıştır. Araştırmada elde edilen veriler betimsel istatistik analizleri, $\mathrm{t}$ testi ve ANOVA yoluyla analiz edilmiştir. Araştırma sonucunda Türkçe öğretmeni adaylarının cinsiyet, yaş grupları, yaşamlarının çoğunu geçirdikleri yer, anne ve baba meslekleri, kardeş sayısı, ailenin ekonomik durumu, anne ve baba eğitim durumları, not ortalamaları, sınıf düzeyleri, sosyal medyada geçirilen süre, internette geçirilen süre ve düzenli gazete takip etme değişkenleri ile ölçeğin boyutları arasında istatistiksel olarak anlamlı bir farklılığın olmadığı görülmektedir. Bu sebeple 16 Türkçe öğretmeni adayından nitel veriler elde edilmiştir. Bu veriler sonucunda Türkçe öğretmeni adaylarının derslere katılım sağlamak, bir şeylerden haberdar olmak, iletişim kurmak, zaman geçirmek ve akıllı telefonların daha kullanışlı olması gibi nedenlerle uzaktan eğitim süresince akıllı telefonlarından yararlandıkları görülmüştür.
Anahtar Kelimeler

Akıllı Telefon

Öz-Yeterlik

21. Yüzyıl Becerileri Türkçe Öğretmeni Adayları

Makale Hakkında

Geliş Tarihi: 03.06.2020

Kabul Tarihi: 28.07.2020

Doi: $10.18026 /$ cbayarsos.747589

\section{Investigation of Pre-ServiveTurkish Teacher Self-Efficacy Using Smart Phone}

\section{Abstract}

The aim of this study is to determine the self-efficacy levels of Turkish teacher candidates using smart phones. For this purpose, the mixed research model was used in the research. The study consisted of a sample group of Turkish teacher candidates studying at a state university located in the west of Turkey. In the data analysis of the research, the "Smart Phone Self-Efficacy Scale", which was validated and valid by Aktay (2018), was used. The data obtained in the study were analyzed through descriptive statistical analysis, t-test and ANOVA. As a result of the research, there is no statistically significant difference between the follow-up variables and the scale's dimensions. For this reason, qualitative data were obtained from 16 Turkish teacher candidates. As a result of these data, it has been observed that Turkish teacher candidates benefit from their smart phones during distance education due to participation in lessons, being aware of something, communicating, spending time and smart phones being more useful.
Keywords

Smartphone

Self-Efficacy

21st-Century Skills

Turkish Language Teacher

About Article

Received: 03.06.2020

Accepted: 28.07.2020

Doi: $10.18026 /$ cbayarsos.747589

a Dr. Öğretim Üyesi, Çanakkale Onsekiz Mart Üniversitesi, Eğitim Fakültesi. ORCID: 0000-0002-1087-4081.

b İletişim Yazarı: fatihkana@hotmail.com

c Dr. Öğretim Üyesi, Çanakkale Onsekiz Mart Üniversitesi, Eğitim Fakültesi. ORCID: 0000-0002-9277-6417.

d Yüksek Lisans Öğrencisi, Çanakkale Onsekiz Mart Üniversitesi, Lisansüstü Eğitim Enstitüsü. ORCID: 0000-0001-6943-0410.

e Okutman, İstanbul Aydın Üniversitesi. ORCID: 0000-0001-6323-1939. 


\section{Giriş}

Öz yeterlik kavramı, bireyin neyi yapıp neyi yapamadığı hakkındaki yargıları olarak ifade edilmektedir (Bandura, 1986). Öz yeterlik dişarıdan algılanan, gözlemlenebilen bir beceri olmamakla birlikte, içsel inanç olarak da görülebilir (Snyder ve Lopez, 2002). Öz yeterlik; kapasite, özel performans hakkındaki inançlarla ilgili olmadığı gibi, bir tür yetenek de değildir (Donald, 2003: 219). Bir kimsenin bir şeyi anlama, yapabilme gücü olan yetenekler, öz yeterlikten farklıdır. Öz yeterlik inancı ise daha genel anlamda belli, özel bir alanda kişinin yeteneklerini kullanarak yapabilecekleridir. Öz yeterliği ifade etmede başarabilme yetisi önem kazanmaktadır. "Ben bu işi başarabilir miyim?" sorusu ile başlayan cümleler öz yeterliği ifade eder. Kişinin söz konusu işi başarabileceğine ilişkin motivasyonu, öz güveni yüksekse öz yeterliği de yüksek olur (Dembo, 2004). Fakat kişinin söz konusu işi başarabileceğine ilişkin motivasyonu, öz güveni gibi çeşitli faktörler eksikse öz yeterliği de düşük olur. Öz yeterliği yüksek olan bireyler zor işlerle karşılaştıkları zaman, kaçmak yerine sorunlarla yüzleşirler. Öz yeterliği düşük olan bireyler ise zor işlerle karşılaştıkları zaman kaçma eğilimi içine girerler, kendilerini söz konusu işten alıkoyarlar, kaçınırlar, çaba göstermezler (Pajares ve Schunk, 2001).

Özyeterlik zamanla ve tecrübeler sayesinde gelişebilir. Bireyler öz yeterliklerini; deneyimleri, gözlemleri ve başkalarının yorumlarını dinlemeleri gibi çeşitli yollarla geliştirebilirler. Öz yeterlik inançlarının tam ve doğru deneyimler, sosyal modeller tarafından sağlanan dolaylı yaşantılar, sözel ikna ve bireyin fiziksel ve duygusal durumu olarak dört temel kaynağ 1 olduğu belirtilmektedir. Bu bilgi kaynakları birbiriyle etkileşim içindedir (Bandura, 1986; Pajares, 2003).

Öz yeterlik algıları üniversite öğrencileri içinde önemli bir etkendir (Ünal ve Şahin, 2013). Öğretmen adaylarının özyeterlik düzeylerini ölçen birçok araştırma yapılmıştır (Bahar, 2019; Gelen, Akçay, Tiryaki ve Benek, 2019; Koçak Macun, Macun ve Safalı, 2019; Recepoğlu ve Recepoğlu, 2019). Bu araştırmalarada bireylerin özyeterlik düzeyleri çeşitli değişkenler açısından incelenmiştir. Günümüzde eğitimin en önemli amaçlarından biri, bireyleri geleceğe hazırlayabilmektir. Eğitim ve öğretim faaliyetleri, öğrencileri gelecekteki rollerine (çalışan, yönetici, ebeveyn vb.) hazırlarsa amacına ulaşmış olur. Bireylerin kendilerinde varolan potansiyellerini ortaya çıkarabilmeleri için bilişsel ve bilişsel olmayan becerilerini geliştirmeye ihtiyaçları vardır (Yalçın, 2018). Yeni dünya düzeninde teknolojinin de gelişmesiyle beraber bireylerin eleştirel düşünme, yaratıcı düşünme, problem çözme gibi üst düzey becerilerini geliştirmeleri gerekmektedir (National Research Council, 2012). Bu durum özellikle gelişmekte olan ülkeler için büyük önem taşımaktadır. Bu noktada içinde yaşanılan çağın takip edilmesi, çağın bilim ve teknolojisine ayak uydurulması eğitimcilerin temel görevlerindendir. $\mathrm{Bu}$ alanda görev alan eğitimcilerin okullarda entellektüel bir uğraşı düşünce ve aktivitelerle birleştirmesi önemlidir. Bu konuda öğretmenlerin eleştirel pedagoji kavramıla ilgili görüşlerini belirten çalışmalar da mevcuttur (Selçuk ve Hursen, 2016; Aksakallı, 2019).

21. yüzyılda pek çok teknolojik gelişme yaşanmış, teknoloji insan hayatının her alanında yerini almıştır. 21. yüzyılda standart bir cep telefonuna kıyasla daha ileri bir teknolojiye sahip olan akıllı telefonların kullanılma oranı giderek artmaktadır. Akıllı telefonların giderek yaygınlaştığı dünyada akıllı telefonlar adeta bir ihtiyaç hâline gelmiştir. Eğitimde de akıllı telefon kullanma oranı öğretmen ve öğrenciler arasında giderek artmaktadır. Özellikle akıllı telefonda yer alan çeşitli uygulamalar öğretmen ve öğrenciler arasında iletişimi ve bilgi 
alışverişini sağlamaktadır. Aynı zamanda akıllı telefonda bulunan eğitici uygulamalar sayesinde öğrenciler eğitime dair çeşitli ihtiyaçlarını da karşılayabilmektedirler.

Son zamanlarda teknolojinin gelişmesiyle birlikte kişiler akıllı telefonlarını sadece iletişim kurmak amacıyla değil, birçok amaç için kullanmaya başlamışlardır. Akıllı telefonlarında bulunan uygulamalardan web sitesini ziyaret edebilmekte, sosyal ağlardan mesaj gönderebilmekte, fotoğraf ve video çekebilmekte, internette arama yapabilmekte, görüntülü görüşme yapabilmekte, fotoğraf ve video gönderebilmekte, ekran görüntüsü alabilmekte, ses kaydı yapabilmekte, takvim girdisi oluşturabilmekte, e-posta yollayabilmekte ve navigasyonu kullanabilmektedir. Bu uygulamalardan kaynaklı da akıllı telefonların kullanım oranı artmaya başlamıştır. Akıllı telefon kullanım oranının her geçen gün artması birtakım sorunların ortaya çıkmasına sebep olmaktadır. Kişiler, akıllı telefonlarından yararlanmak isterken ona bağımlı hale gelmeye başlamışlardır. Teknolojinin ilerlemesiyle birlikte telefonların her geçen gün yenilenmesi kişilerin telefonlarında geçirdiği sürenin artmasına sebep olmaktadır. Bu durum akıllı telefona olan bağımlılığı arttırmakta ve kişiler üzerinde olumsuz sonuçlar ortaya çıkarmaktadır.

Telefon bağımlılığının farklı bir şekilde tanımlanmasını içeren phubbing; İngilizce phone (telefon) ve snubbing (yok sayma, kötüye kullanma) kelimelerinin birleşiminden meydana gelerek oluşturulmuştur (Nazir ve Pişkin, 2016). Phubbing, kişinin her fırsatta akıllı telefonunun ekranına bakıp karşısındaki kişiyi hiç umursamamasıdır. Diğer bir ifadeyle, bireyin sosyal ortamlarda iletişim halindeyken dikkatini akıllı telefona vermesi olarak ifade edilmektedir (Karadağ ve diğ. 2016). Phubbing sadece telefona karşı olan bir bağımlılık değildir. Telefon haricinde internet, oyun ve sosyal medyaya da olan bir bağımlılıktır. Bu bağımlılığ1 gösteren kişilere de "phubber" denilmektedir.

Akıllı telefonla ilgili olan rahatsızlardan bir diğeri de nomofobi rahatsızlığıdır. Bu rahatsızlık, Polat'ın (2017) çalışmasında belirttiği gibi birçok kişinin akıllı telefonu kullanmaya devam etmesi üzerine farkında olmadan yakalandığı bir rahatsızlıktır. Nomofobi, kişinin akıllı telefonlarından uzaklaştıkça stres veya panik yaşaması bunun sonucunda da çevresinde yaşanan olayları algılayamaması ve sürekli olarak mobil cihazını kontrol etme hissine kapılmasıdır. Akıllı telefonların gereğinden fazla kullanılması kişinin bazı sorunlarla karşılaşmasına sebep olmaktadır.

Elektronik uykusuzluk da kişilerin gereğinden fazla akıllı telefon kullanmalarının meydana getirdiği bir rahatsızlıktır. Bu rahatsızlık, internet, bilgisayar, elektronik aletler veya akıllı telefonun aşırı derecede kullanılması sonucu kişilerde bağımlılığa sebep olmakta ve bu aletlere bağlı bağımlılık da uykusuzluk hastalığını meydana getirmektedir. Bu rahatsızlıklar akıllı telefonların günümüz koşullarında önemli bir teknolojik alet haline gelmesindendir. Kişiler akıllı telefonlarını birçok amaç için kullanmakta ve zaman geçtikçe ona bağımlı hale gelmektedir. Bireylerdeki telefon bağımlılığı ile ilgili alanyazında birçok araştırma yapılmıştır (Kuyucu, 2017; Elhai, Levine ve Hall, 2019; Hayırcı, 2019; Özteke Kozan, Kavaklı, Ak ve Kesic, 2019, Şimşek ve Zabun, 2019; Kartol ve Peker, 2020). Alanyazın taramasından görüleceği üzere özyeterlik ve akıllı telefonla ilgili birçok araştırma yapılmasına rağmen öğretmen adaylarının akıllı telefon özyeterlikleriyle ilgili herhangi bir araştırma yapılmadığ görülmektedir.

$\mathrm{Bu}$ araştırmanın amacı Türkçe öğretmeni adaylarının akıllı telefon kullanma öz-yeterlik düzeylerini belirlemektir. Bu amaç doğrultusunda Türkçe öğretmeni adaylarının akıllı 
telefon öz-yeterlik ölçeğindeki maddelere yönelik görüşleri aşağıda belirtilen sorulara yönelik incelenmiştir:

1. Türkçe öğretmeni adaylarının akıllı telefon uygulamasına yönelik görüşleri nelerdir?

2. Türkçe öğretmeni adaylarının akıllı telefon uygulamasına yönelik görüşleri ile cinsiyet, yaş grupları, yaşamlarının çoğunu geçirdikleri yer, anne ve baba meslekleri, kardeş sayısı, ailenin ekonomik durumu, anne ve baba eğitim durumları, not ortalamaları, sınıf düzeyleri, sosyal medyada geçirilen süre, internette geçirilen süre ve düzenli gazete takip etme değişkenleri arasında anlamlı bir ilişki var mıdır?

3. Türkçe öğretmeni adaylarının uzaktan eğitim süresince akıllı telefonlarından yararlanma nedenleri nelerdir?

4. Türkçe öğretmeni adaylarının akıllı telefonun hayatımızı kolaylaştırıp kolaylaştırmadığına yönelik görüşleri nelerdir?

5. Türkçe öğretmeni adayları akıllı telefonlarından hangi konularda arama yapmaktadır?

6. Türkçe öğretmeni adaylarının akıllı telefonun toplum üzerindeki olumlu ve olumsuz yönlerine yönelik görüşleri nelerdir?

7. Türkçe öğretmeni adaylarının akıllı telefon uygulamasının avantaj ve dezavantajlarına yönelik görüşleri nelerdir?

8. Türkçe öğretmeni adaylarının kullandıkları akıllı telefon uygulamaları nelerdir?

9. Türkçe öğretmeni adayları 'kişinin akıllı telefon ekranına bakıp, karşısındaki kişiyi hiç umursamamasının bir elektronik hastalık olduğunu' bilyor mudur? Bu rahatsızlık kişide veya çevresinde var mıdır? Bu elektronik rahatsızlığın tedavisine yönelik görüşleri nelerdir?

\section{Yöntem}

\section{Araştırma Modeli}

Araştırmada karma araştırma desenlerinden karma çeşitleme deseni kullanılmıştır. Bu desen nicel veriler, nitel verilerle genişletilmek istenildiğinde kullanılmaktadır (Creswell ve Plano Clark, 2007; Alkan, Şimşek ve Armağan Erbil, 2019). Araştırmada Türkçe öğretmeni adaylarının akıllı telefon özyeterlik düzeylerini tespit etmek için öncellikle bir ölçek kullanılmıştır. Ölçekle elde edilen verilerin genişletilmesi amacıyla yarı yapılandırılmış görüşme formu kullanılmıştır. Bu desenin kullanılmasının amacı araştırmanın nicel bölümünde toplanan verileri genişletmektir.

\section{Evren ve Örneklem / Çalışma Grubu}

Araştırmanın örneklem grubunu Türkiye'nin batısındaki bir devlet üniversitesinde öğrenim gören 204 Türkçe öğretmeni adayı oluşturmaktadır. Araştırmanın örneklem grubuna dair tanımlayıcı istatistik analizleri verilmiştir.

Tablo 1. Araştırmaya Katılanların Cinsiyetleri

\begin{tabular}{ccc}
\hline Cinsiyet & f & \% \\
\hline Kadın & 137 & 67.2 \\
Erkek & 67 & 32.8 \\
\hline
\end{tabular}


Tablo 1 incelendiğinde araştırmaya katılan öğretmen adaylarının \%67.2'sinin kadın, \%32.8'sinin erkek olduğu görülmektedir.

Tablo 2. Araştırmaya Katılan Öğretmen Adaylarının Yaş Grupları

\begin{tabular}{ccc}
\hline Yaş & f & \% \\
\hline 18 & 9 & 4.4 \\
19 & 28 & 13.7 \\
20 & 46 & 22.5 \\
21 & 54 & 26.5 \\
22 & 43 & 21.1 \\
23 ve üzeri & 21 & 11.8 \\
\hline
\end{tabular}

Tablo 2 incelendiğinde araştırmaya katılan öğretmen adaylarının \%4.4'ünün 18 yaş, \%13.7'sinin 19 yaş, \%22.5'inin 20 yaş, \%26.5'inin 21 yaş, \%21.1'inin 22 yaş, \%11.8'inin 23 ve üzeri yaş grubunda olduğu görülmektedir.

Tablo 3. Araştırmaya Katılanların Yaşamlarını Geçirdikleri Yerle ilgili Tanımlayıcı İstatistik Analizleri

\begin{tabular}{|c|c|c|}
\hline Yaşamını Geçirdiği Yer & f & $\%$ \\
\hline Köy & 24 & 11.8 \\
\hline Kasaba & 27 & 13.2 \\
\hline Şehir & 74 & 36.3 \\
\hline Büyükşehir & 79 & 38.7 \\
\hline
\end{tabular}

Tablo 4. Araştırmaya Katılanların Kardeş Sayıları

\begin{tabular}{ccc}
\hline Kardeş Sayıları & $\mathbf{f}$ & \% \\
\hline 1 & 9 & 4.4 \\
2 & 94 & 46.1 \\
3 & 58 & 28.4 \\
4 & 17 & 8.3 \\
5 ve üzeri & 26 & 12.7 \\
\hline
\end{tabular}

Tablo 4 incelendiğinde araştırmaya katılan öğretmen adaylarının \%4.4'ünün tek çocuk, \%46.1'inin 2, \%28,4'ünün 3, \%8.3'ünün, 4 ve \%12.7'sinin 5 ve üzeri kardeşi olduğu görülmektedir. 
Tablo 5. Araştırmaya Katılanların Annelerinin Eğitim Durumu

\begin{tabular}{ccc}
\hline Anne Eğitim Durumu & $\mathbf{f}$ & $\mathbf{\%}$ \\
\hline Okur-yazar değil & 8 & 3.9 \\
Okur-yazar & 14 & 6.9 \\
İlkokul & 112 & 54.9 \\
Ortaokul & 26 & 12.7 \\
Lise & 36 & 17.6 \\
Üniversite & 8 & 3.9
\end{tabular}

Tablo 5 incelendiğinde araştırmaya katılan öğretmen adaylarının annelerinin \%3.9'unun okur-yazar değil, \%6.9'unun okur-yazar, \%54.9'unun ilkokul, \%12.7'sinin ortaokul, \%17.6'sının lise, \%3.9'unun üniversite mezunu olduğu görülmektedir.

Tablo 6. Araştırmaya Katılanların Babalarının Eğitim Durumu

\begin{tabular}{ccc}
\hline Baba Eğitim Durumu & $\mathbf{f}$ & \% \\
\hline Okur-yazar değil & 3 & 1.5 \\
Okur-yazar & 2 & 1.0 \\
İlkokul & 74 & 36.3 \\
Ortaokul & 53 & 26.0 \\
Lise & 44 & 21.6 \\
Üniversite & 28 & 13.7
\end{tabular}

Tablo 6 incelendiğinde araştırmaya katılan öğretmen adaylarının babalarının \%1.5'inin okuryazar değil, \%1'inin okur-yazar, \%36.3'ünün ilkokul, \%26'sının ortaokul, \%21.6'sının lise, \%13.7'sinin üniversite mezunu olduğu görülmektedir.

Tablo 7. Araştırmaya Katılanların Not Ortalamaları

\begin{tabular}{ccc}
\hline Not Ortalamaları & $\mathbf{f}$ & $\%$ \\
\hline $0-2.5$ & 15 & 7.4 \\
$2.51-3.00$ & 76 & 37.3 \\
$3.01-4.00$ & 113 & 55.4 \\
\hline
\end{tabular}

Tablo 7 incelendiğinde araştırmaya katılan öğretmen adaylarının not ortalamalarının \%7.4'ünün 0-2.5 arasında olduğu, \%37.3'ünün 2.51-3.00 arasında olduğu, \%55.4'ünün ise 3.01-4.00 arasında olduğu görülmektedir.

Tablo 8. Araştırmaya Katılanların Sınıf Düzeyleri

\begin{tabular}{ccc}
\hline Sınıf Düzeyleri & $\mathbf{f}$ & $\%$ \\
\hline 1 & 35 & 17.2 \\
2 & 55 & 27.0 \\
3 & 66 & 32.4 \\
4 & 48 & 23.5 \\
\hline
\end{tabular}


Tablo 8 incelendiğinde araştırmaya katılan öğretmen adaylarının sınıf düzeylerinin \%17.2'sinin 1., \%27'sinin 2., \%32.4'ünün 3., \%23.5' inin 4. sinıf olduğu görülmektedir.

Tablo 9. Araştırmaya Katılanların Sosyal Medyada ve İnternette Geçirdikleri Süre

\begin{tabular}{ccccc}
\hline & \multicolumn{2}{c}{ Sosyal Medyada Geçirilen Süre } & \multicolumn{2}{c}{ Internette Geçirilen Süre } \\
& $\mathbf{f}$ & $\mathbf{\%}$ & $\mathbf{f}$ & $\%$ \\
\hline Yok & 2 & 1.0 & & 77.5 \\
$0-5$ & 183 & 89.7 & 158 & 21.6 \\
$6-10$ & 17 & 8.3 & 44 & 1.0 \\
$11-15$ & 2 & 1.0 & 2 & $\%$ \\
\hline
\end{tabular}

Tablo 9 incelendiğinde araştırmaya katılan öğretmen adaylarının sosyal medyada \%1'inin sosyal medyada hiç vakit geçirmediği, \%89.7'sinin $0-5$, \%8.3'ünün 6-10, \%1'inin ise 11-15 saat arasında vakit geçirdiği görülmektedir. Öğretmen adaylarının \%77.5'inin 0-5; \%21,6'sının 610 ve \%1'inin 11-15 saat arasında internette vakit geçirdikleri görülmektedir.

Araştırmanın nitel çalışma grubunu, nicel bölümde ölçeği dolduran 16 Türkçe öğretmeni adayı oluşturmaktadır. Araştırmanın nicel verilerinden en yüksek ortalamaya ve en düşük ortalamaya sahip öğretmen adayları araştırmanın çalışma grubunu oluşturmuştur.

\section{Veri Toplama Araçları}

Araştırmada nicel veri toplama aracı olarak Aktay (2018) tarafından geçerliği ve güvenirliği yapılmış “Akıllı Telefon Öz-Yeterlik Ölçeği” kullanılmıştır. Ölçek, öğretmen adaylarının akıllı telefon öz-yeterliklerini ölçmek amacıyla hazırlanmıştır. Ölçek kullanılmadan önce ölçek sahiplerinden gerekli izinler alınmıştır. Ölçekte toplam 20 madde bulunmaktadır. Aktay (2018) tarafından ölçeğin yapı geçerliğini test etmek için Kaiser-Meyer-Olkin $(\mathrm{KMO}=0.96)$, Bartlett testi $\left(\mathrm{x}^{2}=18933.563 ; \mathrm{df}=861,(\mathrm{p}=0.000)\right)$ analizler yapılmış ve ölçeğin yapı geçerliğine uygun olduğu görülmüştür. Ölçek uygulaması için gerekli izinler alındıktan sonra araştırmacılar tarafından ölçeğe yeniden açımlayıcı faktör analizi yapılmıştır. Yapılan analiz sonucunda (Kaiser-Meyer-Olkin $(\mathrm{KMO}=0.94)$, Bartlett testi $\left(\mathrm{x}^{2}=4531,774 ; \mathrm{df}=190\right.$ $(\mathrm{p}=0.000)$ ölçeğin yapı geçerliğinin uygun olduğu ve 2 faktörlü bir yapının ortaya çıktığ1 görülmüştür. Ölçekten elde edilen verilere göre faktörler, akıllı telefonla ilgili teknik özelliklerin farkında olma, akıllı telefonla ilgili üst düzey uygulamalar yapma olarak isimlendirilmiştir.

Araştırmanın nitel verileri yarı yapılandırılmış görüşme formu aracılığıyla toplanmıştır. Önce araştırmacılar tarafından taslak bir form oluşturulmuştur. Bu taslak form alanında uzman öğretim üyelerine gönderilmiştir. Öğretim üyelerinden gelen görüşler doğrultusunda forma son hali verilip bir öğretmen adayıyla pilot bir uygulama yapılmıştır. Pilot uygulama sonunda forma son hali verilip form uygulanmıştır.

\section{Verilerin Toplanması ve Analizi}

$\mathrm{Bu}$ araştırmada veriler internet üzerinden Türkçe öğretmeni adaylarına ulaştırılmış ve öğretmen adaylarının görüşlerine de yine bu sistem üzerinden ulaşılmıştır. Toplanan veriler SPSS25 paket programı yoluyla toplanmıştır. Akıllı Telefon Öz yeterlik ölçeğinden alınan puanların güvenirliğini belirlemek için, Cronbach Alfa iç tutarlılık hesaplamaları yapılmıştır. Ölçeğin 20 maddelik hesaplanan Cronbach Alfa değeri 0.97 şeklindedir. Cronbach Alfa 
değerinin 0.80 'in üzerinde olması ölçeğin güvenilir olduğunu göstermektedir $(\mathrm{p}<0.05)$. Araştırmadan elde edilen verilerin normal dağılım gösterip göstermediğini belirlemek için çarpıklık ve basıklık değerleri hesaplanmıştır. Araştırmanın verileri normal dağılım gösterdiğinden araştırmada yer alan analizler için parametrik testler uygulanacaktır. Araştırmada elde edilen verilere açımlayıcı faktör analizi, tanımlayıcı istatistiksel analizler, $\mathrm{t}$ testi ve ANOVA ve korelasyon analizi uygulanmıştır. Araştırmanın nitel verilerini analiz edebilmek amacıyla betimsel analiz tekniği kullanılmıştır. Betimsel analizde araştırmacı tarafından önceden temalar belirlenir ve analizler bu temalara göre yapılır. Araştırmada analizlerin güvenilir ve geçerli olabilmesi için farklı araştırmacılar tarafından kodlamalar yapilmiştır.

\section{Etik Kurulu İzni}

Araştırmanın etik kurulu izni, Çanakkale Onsekiz Mart Üniversitesi Sosyal Bilimler ve Eğitim Bilimleri Etik Kurulu 16.04.2020 tarih 03 nolu kararıyla alınmıştır. Ayrıca araştırmaya katılanlar araştırmaya gönüllü olarak katıldıklarını beyan etmişlerdir.

\section{Bulgular}

Araştırmanın bu bölümünde araştırma sürecinde elde edilen veriler analiz edilecek ve yorumlanacaktır.

Tablo 10. Akıllı Telefonla İlgili Teknik Özelliklerin Farkında Olma Boyutuna İlişkin Tanımlayıcı İstatistik Analizleri

\begin{tabular}{|c|c|c|c|c|}
\hline Boyut Adı & Maddeler & $\overline{\mathbf{X}}$ & ss & $\begin{array}{c}\text { Genel } \\
\text { Ortalama }\end{array}$ \\
\hline \multirow{11}{*}{$\begin{array}{c}\text { Akıllı } \\
\text { Telefonla } \\
\text { İlgili } \\
\text { Teknik } \\
\text { Özelliklerin } \\
\text { Farkında } \\
\text { Olma }\end{array}$} & Akıllı telefonum ile fotoğraf ve video çekebilirim. & 4.86 & .429 & \multirow{11}{*}{4.79} \\
\hline & Akıllı telefonum ile internette arama yapabilirim. & 4.85 & .463 & \\
\hline & Akıllı telefonumun ekran görüntüsünü alabilirim. & 4.84 & .507 & \\
\hline & Akıllı telefonum ile sosyal ağlardan mesaj gönderebilirim. & 4.82 & .523 & \\
\hline & Akıllı telefonumdaki bir dosyayı ya da klasörü silebilirim. & 4.82 & .514 & \\
\hline & Akıllı telefonumdan kablosuz ağlara bağlanabilirim. & 4.81 & .538 & \\
\hline & $\begin{array}{l}\text { Akıllı telefonumun ekranındaki bir metni seçip } \\
\text { kopyalayabilirim. }\end{array}$ & 4.78 & .660 & \\
\hline & Akıllı telefonum ile ses kaydı yapabilirim. & 4.78 & .613 & \\
\hline & Akıllı telefonumdan bir web sitesini ziyaret edebilirim. & 4.76 & .587 & \\
\hline & $\begin{array}{lcc}\text { Akıllı telefonumdaki } & \text { fotoğraflardan } & \text { gereksinim } \\
\text { duyduğuma ulaşabilirim. } & \end{array}$ & 4.73 & .570 & \\
\hline & $\begin{array}{l}\text { Akıllı telefona uygulama marketindeki uygulamayı } \\
\text { yükleyebilirim. }\end{array}$ & 4.62 & .722 & \\
\hline
\end{tabular}

Tablo incelendiğinde öğretmen adaylarının akıllı telefon kullanma öz yeterliklerinin üst düzeyde olduğu söylenebilir. Öğretmen adayları akıllı telefonlarıyla fotoğraf ya da video çekebilmekte, internette arama yapabilmekte, ekran görüntüsünü alabilmekte, sosyal ağlardan mesaj gönderebilmekte, bir dosyayı ya da klasörü silebilmekte, kablosuz ağlara bağlanabilmekte, ekranındaki bir metni seçip kopyalayabilmekte, ses kaydı yapabilmekte, bir web sitesini ziyaret edebilmekte, fotoğraflardan gereksinim duyduklarına ulaşabilmekte, uygulama marketindeki uygulamayı yükleyebilmektedir. 
Tablo 11. Akıllı Telefonla İlgili Üst Düzey Uygulamalar Yapma Boyutuna İlişkin Tanımlayıcı İstatistik Analizleri

\begin{tabular}{|c|c|c|c|c|}
\hline Boyut Adı & Maddeler & $\overline{\mathbf{X}}$ & ss & $\begin{array}{c}\text { Genel } \\
\text { Ortalama }\end{array}$ \\
\hline \multirow{9}{*}{$\begin{array}{c}\text { Akıllı } \\
\text { Telefonla } \\
\text { İlgili Üst } \\
\text { Düzey } \\
\text { Uygulamalar } \\
\text { Yapma }\end{array}$} & $\begin{array}{l}\text { Akıllı telefonumla sosyal ağ uygulamaları üzerinden } \\
\text { görüntülü görüşme yapabilirim. }\end{array}$ & 4.81 & .565 & \multirow[b]{10}{*}{$\begin{array}{l}\text { sunda öz } \\
\text { sosyal ağ } \\
\text { e yeniden } \\
\text { z internet } \\
\text { afızasında } \\
\text { kaldığını } \\
\text { eri tarihte } \\
\text { avigasyon } \\
\text { ün adını }\end{array}$} \\
\hline & $\begin{array}{l}\text { Akıllı telefonumdan resimleri kırpma ve yeniden } \\
\text { boyutlandırma gibi düzenleme } \\
\text { gerçekleştirebilirim. }\end{array}$ & 4.77 & .641 & \\
\hline & $\begin{array}{l}\text { Akıllı telefonumun mobil veri internetini kablosuz } \\
\text { internet olarak diğer cihazlara paylaştırabilirim. }\end{array}$ & 4.75 & .684 & \\
\hline & $\begin{array}{l}\text { Akıllı telefonumda kurulu olan uygulamaların telefon } \\
\text { hafızasında ne kadar yer kapladığına bakabilirim. }\end{array}$ & 4.73 & .659 & \\
\hline & $\begin{array}{l}\text { Akıllı telefonumda ne kadar disk alanım kaldığını } \\
\text { öğrenebilirim. }\end{array}$ & 4.71 & .693 & \\
\hline & Akıllı telefonumdan e-posta yollayabilirim. & 4.71 & .656 & \\
\hline & $\begin{array}{l}\text { Akıllı telefonumdan bir görev ya da iş ile ilgili olarak } \\
\text { ileri tarihte hatırlatmak üzere takvim girdisi } \\
\text { oluşturabilirim. }\end{array}$ & 4.69 & .719 & \\
\hline & $\begin{array}{l}\text { Akıllı telefonumdaki navigasyon uygulamaların } \\
\text { kullanabilirim. }\end{array}$ & 4.63 & .739 & \\
\hline & Akıllı telefonumdaki bir klasörün adını değiştirebilirim. & 4.64 & .814 & \\
\hline \multicolumn{4}{|c|}{$\begin{array}{l}\text { Öğretmen adaylarının akıllı telefonla ilgili üst düzey uygulamalar konusunda öz } \\
\text { yeterliklerinin yüksek olduğu söylenebilir. Öğretmen adayları akıllı telefonlarıla sosyal ağ } \\
\text { uygulamaları üzerinden görüntülü görüşme yapabilmekte, resimleri kırpma ve yeniden } \\
\text { boyutlandırma gibi işlemleri düzenleyebilmekte, mobil veri internetini kablosuz internet } \\
\text { olarak diğer cihazlara paylaştırabilmekte, telefonundaki uygulamaların telefon hafızasında } \\
\text { ne kadar yer kapladığına bakabilmekte, telefonundaki disk alanının ne kadar kaldığını } \\
\text { öğrenebilmekte, e-posta yollayabilmekte, bir görev ya da iş ile ilgili olarak ileri tarihte } \\
\text { hatırlatmak üzere takvim girdisi oluşturabilmekte, telefonundaki navigasyon } \\
\text { uygulamalarını kullanabilmekte ve telefonundaki herhangi bir klasörün adını } \\
\text { değiştirebilmektedir. }\end{array}$} & \\
\hline
\end{tabular}

Tablo 12. Öğretmen Adaylarının Akıllı Telefonla İlgili Teknik Özelliklerin Farkında Olmaları ile Akıllı Telefonla İlgili Üst Düzey Uygulamalar Yapmaları Arasındaki İlişki

Akıllı Telefonla İlgili Teknik Akıllı Telefonla İlgili Üst

Özelliklerin Farkında Olma Düzey Uygulamalar Yapma

\begin{tabular}{lcc}
\hline Akıllı Telefonla İlgili Teknik & 1 & $.851^{* *}$ \\
Özelliklerin Farkında Olma & & 1 \\
Akıllı Telefonla İlgili Üst Düzey & $.851^{* *}$ & 1 \\
Uygulamalar Yapma & & \\
\hline
\end{tabular}

\footnotetext{
${ }^{* *} \mathrm{p}<0.01$ anlamlılık seviyesinde ilişki anlamlı
} 
Tablo 12 incelendiğinde, akıllı telefonla ilgili teknik özelliklerin farkında olma ile akıllı telefonla ilgili üst düzey uygulamalar yapma arasında pozitif yönde yüksek düzey bir ilişkinin olduğu görülmektedir.

\section{Araştırmanın Nitel Bulguları}

Tablo 13. Türkçe Öğretmeni Adaylarının Uzaktan Eğitim Süresince Akıllı Telefonlarından Yararlanma Nedenlerine Yönelik Görüşleri

\begin{tabular}{cc}
\hline Yararlanma Nedenleri & f \\
\hline Derslere katılım sağlamak & 6 \\
Haberdar olma & 2 \\
İletişim kurmak & 2 \\
Zaman geçirme & 1 \\
\hline
\end{tabular}

Türkçe öğretmeni adayları dünyada ve Türkiye'de meydana gelen COVİD 19 süresince üniversitelerdeki derslerine uzaktan eğitim yoluyla katılmışlardır. Öğretmen adayları pandemi süresince akıllı telefonlarından derslere katılım sağlamak $(n=6)$, bir şeylerden haberdar olmak $(n=2)$, iletişim kurmak $(n=1)$, zaman geçirmek $(n=1)$ ve daha kullanışlı olmasından $(n=1)$ dolayı uzaktan eğitim süresince derslere katılmak için yararlanmışlardır. Bu konuda öğretmen adaylarının görüşleri şu şekildedir:

Ö3: "Akıllı telefonu iletişim ve zaman geçirme amaçl sosyal medya."

Ö4: "Çok faydalandım. Cep telefonu paylaşılanlardan zamanında haberdar olmak ve dersleri düzenli takip edip haberleşebilmem için önemli bir yardımcı haline geldi."

Ö5: "Sıklıkla yararlandım. Ders konusunda ve çalışmalarım konusunda oldukça yararın gördüm."

Ö6: "Teams uygulamasın telefonuma yükleyerek uzaktan eğitim derslerime katılabildim. Bilgisayar herkeste bulunmayabiliyor ve telefonlar bu süreçte oldukça faydalı oldu."

Ö15: "Bilgisayarı açıp oturmaktansa telefon her durumda daha kullanışlı oldu. Yatarken, otururken her durumda telefonlarımizı kullanabilirim."

Tablo 14. Türkçe Öğretmeni Adaylarının Akıllı Telefonun Hayatımızı Kolaylaştırıp Kolaylaştırmadığına Yönelik Görüşleri

\begin{tabular}{lcll}
\hline \multicolumn{1}{c}{ Akıllı Telefon Uygulaması } & f & Akıllı Telefon Uygulaması & f \\
\hline Hayatımızı kolaylaştırıyor & 12 & Hayatımızı kolaylaştırmıyor & 2 \\
Bilgiye ulaşılabilirlik & 8 & Zamanı tüketmek & 2 \\
İletişimi sağlama & 8 & Bağımlılık yapma & 1 \\
Tüm işlemlerin yapılabilmesi & 5 & Monotonluk & 1 \\
İhtiyaçları giderebilme & 4 & & \\
Duyurulardan haberdar olma & 3 & & \\
Kendini daha rahat ifade etme & 2 & \\
Bilgiyi depolama & 1 &
\end{tabular}


Sosyalleşme

Akıllı telefon hem hayatımızı kolaylaştırıyor hem de kolaylaştırmıyor
1

3

Türkçe öğretmeni adaylarından bazıları akıllı telefonların hayatı kolaylaştırdı̆̆ını düşünürken ( $n=12)$, bazıları ise hayatı kolaylaştırmadığını düşünmektedir $(n=2) .3$ öğretmen adayı da akıllı telefonun hem hayatı kolaylaştırdığını hem de kolaylaştırmadığını düşünmektedir. Türkçe öğretmeni adayları bilgiye ulaşılabilirlik $(\mathrm{n}=8)$, iletişimi sağlama $(n=8)$, tüm işlemlerin yapılabilmesi $(n=5)$, ihtiyaçları giderebilme $(n=4)$, duyurulardan haberdar olma $(n=3)$, kendini daha rahat ifade etme $(n=2)$, bilgiyi depolama $(n=1)$ ve sosyalleşme $(n=1)$ açısından akıllı telefonların hayatlarını kolaylaştırdığını düşünmektedir. Türkçe öğretmeni adaylarının bazıları ise zamanı tükettiğinden ( $n=2)$, bağımlılık yaptığından $(n=1)$ ve monotonluğa sebep olduğundan $(n=1)$ dolayı akıllı telefonun hayatlarını kolaylaştırmadığını düşünmektedir.

Ö1: "Kolaylaştırıyo. Her bilgi hemen elinin altında, sadece bilgi değil tüm işlemler telefonla artık rahatlıkla yapılıyor."

Ö2: "Akıllı telefonlar hayatın bazı noktaların da işlerimizi kolaylaştırır örnek bir bilgiye ya da makaleye kolayca ulaşabiliriz fakat telefona bağımlı bir şekilde yaşarsak zamanımızdan çok vakit çalabilir."

Ö3: "Kolaylaştırıyor. İstediğimiz an istediğimiz bilgilere ulaşmamızı să̆lıyor. Uzakta olan sevdiklerimizin sesini duymamızı ve görmemizi sağhlyor."

Ö5: "Kolaylaştırıyor. Eskiden onlarca kitaptan edinebileceğimiz bilgileri internetten aratarak, online kütüphanelerden veya pdf'lerden rahat bir şekilde edinebiliyoruz."

Ö6: "Tamamen kolaylaştırdığını düşünüyorum. Bilgiye ulaşın akıllı telefonlar sayesinde artık çok daha kolay. Örneğin haberleri okumak, bir sözcü̈̆̈̈̈ yazımını öğrenmek vs. oldukça kolay."

Ö7: "Bence kolaylaştırıyor. Aklımıza gelebilecek çoğu şeyi tek tıkla yapabileceğimiz yakınlığa getiriyor. Zaman açısından birçok işimizde kolaylık sağladığı aşikâr. Bunun yanında sıra tabi ki insanın zamanın tüketmesi ki bu bizim uzun süre kullanmamızdan dolayı olsa da çok fazla zaman harcıyoruz ve bunun sonucunda zamanımızın çoğu telefonda geçiyor bu açıdan da günü kısalttı̆̆ı için hayatımı bir tık zorlaştırıyor diyebilirim."

Ö10: "Akıllı telefon hayatımızı kolaylaştırıyor. Çünkü hemen herkesle kolay bir şekilde iletişime geçebiliyoruz. Acil durumlarda birçok şeyi telefondan öğrenebiliyoruz."

Ö11: “ Kolaylaştırıyor. Hepimizin evlerde kaldı̆̆ı günlerde büyüklerimizle ve arkadaşlarımızla hem görüntülü hem sesli görüşme imkânı sağlıyor."

Ö15: "Kolaylaştırıyor. Hepimizin evlerde kaldığı günlerde büyüklerimizle ve arkadaşlarımızla hem görüntülü hem sesli görüşme imkânı să̆lıyor." 
Tablo 15. Türkçe Öğretmeni Adaylarının Akıllı Telefonda Arama Yaptıkları Konulara İlişkin Cevaplar1

\begin{tabular}{cc}
\hline Arama Yaptıkları Konular & $\mathbf{f}$ \\
\hline Ödev konuları & 8 \\
Araştırma konuları & 8 \\
Hobiler & 7 \\
Güncel konular & 5 \\
Sosyal medya & 3 \\
Eğitsel konular & 3 \\
Tarihi konular & 1 \\
\hline
\end{tabular}

Türkçe öğretmeni adayları akıllı telefonlarından ödev konularını $(\mathrm{n}=8)$, araştırma konularını $(n=8)$, hobilerini $(n=7)$, güncel konuları $(n=5)$, sosyal medyayı $(n=3)$, eğitsel konuları $(n=3)$ ve tarihî konuları $(n=1)$ araştırmaktadırlar.

Ö4: "Dersler, makaleler, güncel konular, haberler, yemek tarifleri, hobilerim, sosyal medya gibi pek çok alanda arama yapıyorum."

Ö6: "Akıllı telefonumla dersler ile ilgili bilgilere ulaşabiliyorum. Dizi izlemek, haber okumak vs. gibi aktiviteler için de akıllı telefonumu kullanıyorum."

Ö7: "Genel olarak gün içerisinde ders çalışırken, ödev yaparken ya da herhangi duydŭ̆um ve bilmediğim bir şey hakkında araştırma yaparım."

Ö8: "Daha çok tarihi ve güncel konularda araştırma yapıyorum. Aynı şekilde sağlık konusunda da bilgi edinmek için araştırma yaptığım oluyor."

Tablo 16. Türkçe Öğretmeni Adaylarının Akıllı Telefonun Zaman Kaybı Olup Olmadığına Yönelik Görüşleri

\begin{tabular}{llll}
\hline \multicolumn{1}{c}{ Akıllı Telefon Uygulaması } & f & \multicolumn{1}{c}{ Akıllı Telefon Uygulaması } & f \\
\hline Zaman kaybıdır & 8 & Zaman kaybı değildir & 4 \\
Sosyal medyada geçirilen süre & 6 & Bilgiye kolay ulaşılabilirlik & 1 \\
Bağımlılık yapması & 2 & Ekonomiklik & 1 \\
& & İhtiyaçları giderebilme & 1 \\
\hline
\end{tabular}

Türkçe öğretmeni adaylarının 8'i akıllı telefonu zaman kaybı olarak görürken, öğretmen adaylarının 4'ü ise akıllı telefonu zaman kaybı olarak görmemektedir. Akıllı telefonu zaman kaybı olarak gören Türkçe öğretmeni adayları sosyal medyada geçirilen sürenin fazlalığından $(n=6)$ ve akıllı telefonun kişilerde bağımlılık yapmasından $(n=2)$ dolayı böyle düşündüklerini ifade etmektedir. Akıllı telefonu zaman kaybı olarak görmeyen Türkçe öğretmeni adayları ise bilgiye kolay ulaşabildikleri $(n=1)$, ekonomikliği sağladığı $(n=1)$ ve ihtiyaçları giderebildiği için $(n=1)$ böyle düşündüklerini belirtmektedir. 
Ö2: "Evet zaman kaybı olabiliyor. Nedeni ise akıllı telefonların insanlar üzerinde bağımlılık yaptığını düşünüyorum. Bu sebepten dolayı insanlar ellerinden hiç ayırmıyor. bu da zaman kaybina neden oluyor."

Ö5: "Akıllı telefonun zaman kaybı olduğunu düşünmüyorum aksine zamanı daha ekonomik duruma getiriyor. İstediğimiz her şey bir tıkla önümüze geliyor."

Ö6: "Akıllı telefonların zaman kaybı olduğunu düşünmüyorum. Özellikle bilgiye ulaşma konusunda akıllı telefonlar olmasa oldukça çok zaman kaybı yaşayabilirdik."

Ö7: "Akıllı telefon bir açıdan birçok şeyde zamandan ekonomiklik sağlasa da sosyal medyalara ayırdığımız zaman yüzünden akıllı telefonlarda çok fazla zamanımızı kaybettiğimizi düşünüyorum."

Ö16: "Sosyal medya biraz zaman kaybı olabilir ama o akıll telefonun zaman kaybettirdiği anlamına gelmez. Çünkü sosyal medya kullanımı bir seçimdir."

Tablo 17. Türkçe Öğretmeni Adaylarının Akıllı Telefonun Toplum Üzerindeki Olumlu ve Olumsuz Yönlerine Yönelik Görüşleri

\begin{tabular}{llll}
\hline \multicolumn{1}{c}{ Toplum Üzerindeki Olumlu Yönleri } & $\mathbf{f}$ & Toplum Üzerindeki Olumsuz Yönleri & $\mathbf{f}$ \\
\hline Toplum üzerinde olumlu bir yönü vardır. & 1 & Toplum üzerinde olumsuz bir yönü vardır. & 8 \\
İhtiyaçları giderebilme & 5 & Asosyallik & 6 \\
Bilgiye ulaşılabilirlik & 4 & Sağlık problemleri & 4 \\
Erişilebilirlik & 4 & Bilgi kirliliği & 4 \\
İletişim kolaylığı & 4 & İletişim kopukluğu \\
Güncellik & 1 & Zaman kaybı & 2 \\
Kişisel gelişime yardımcı olma & 1 & Bağımlılık & 2 \\
$\begin{array}{l}\text { Toplum üzerinde hem olumlu hem } \\
\text { olumsuz etkisi vardır. }\end{array}$ & 7 & & 2 \\
\end{tabular}

Türkçe öğretmeni adaylarının 8'i akıllı telefonun toplum üzerinde olumsuz bir etkisi olduğunu düşünürken, öğretmen adaylarının 1'i ise akıllı telefonun toplum üzerinde olumlu bir etkisi olduğunu düşünmektedir. Türkçe öğretmeni adaylarının 7'si ise akıllı telefonun toplum üzerinde hem olumlu hem olumsuz etkisi olduğunu düşünmektedir. Öğretmen adayları ihtiyaçları giderebildiğinden $(n=5)$, bilgiye ulaşılabilirliğinden $(n=4)$, erişilebilirlikten $(n=4)$, iletişim kolaylığından $(n=4)$, güncelliği sağlamasından $(n=1)$ ve kişisel gelişime yardımcı olmasından $(n=1)$ dolayı akıllı telefonun toplum üzerinde olumlu bir etkisinin olduğunu düşünmektedir. Öğretmen adaylarının bazıları ise asosyalliğe sebep olmasından $(n=6)$, birtakım sağlık problemlerinin yaşanmasına neden olduğundan $(n=4)$, bilgi kirliliği meydana getirmesinden $(n=4)$, iletişim kopukluğuna sebep olmasından $(n=2)$, zaman kaybı yaratmasından $(n=2)$ ve insanlarda bağımlılığa $(n=2)$ sebep olmasından dolayı akıllı telefonun toplum üzerinde olumsuz bir etkisinin olduğunu düşünmektedir.

Ö2: "Olumlu etkisi doğru bir bilgi veya güzel bir toplumsal olayın insanlara kolayca ulaştırabiliyor fakat kısa bir sürede olumsuz bir toplumsal olayı da kolayca insanlara ulaştırabiliyor." 
Ö4: "Bilgiye ulaşmayı, haberleşmeyi, iş yaşamını kolaylaştırdığı için olumlu. Bununla birlikte sosyal medya da insanların bir kısmı sanal yaşamlar ve arkadaşlıklar oluşturuyor. Bu şekilde psikolojik olarak kendilerini kandırdıkları bir dünya oluşturmalarma neden oluyor. Bu da insanlarm özenti yaşamlar oluşturmalarına, tüketimin fazlalaşmasina, tükettiğgi kadar üretmeyen insanların ortaya çıkmasına neden olmakta. Bu gibi şeyler olumsuz etkilerini oluşturuyor."

Ö5: "Genel olarak toplum üzerindeki etkisine baktığımda insanları olumsuz etkilediğini düşünüyorum. Çünkü vakit geçirmek ve eğlenmek için zaman8 verimsizleştirdiklerini düşünüyorum."

Ö6: "Insanların araştırması, öğrenmesi vb. amaçlar için akıllı telefonları oldukça faydalı buluyorum. Bunun yanında ne yazık ki akıllı telefonlar bazen olumsuz sonuçlar doğurabiliyor. Insanların birbirleriyle sohbet etmemeleri, göze zarar vermesi, çocukların akıllı telefonla çok vakit geçirmesi ve bundan dolayı dişarda oyun oynamamaları kas gelişimini olumsuz etkilemektedir. Bunlar akıllı telefonların olumsuz özellikleri içerisinde sayılabilir."

Ö12: “Olumlu etkisi uzaktakilerle iletişimi kolaylaştırıyor, kaybolduğumuzda yerimizi yönümüzü bulabiliyoruz. Olumsuz yanları yakınlarla iletişimi koparıyor ve kullanımı

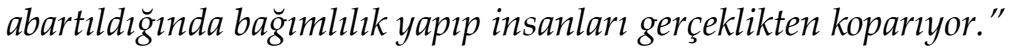

Ö13: “Toplumu çă̆a uygun hale getirme, gelişime yardımcı olma ve kolaylık sağlama açısından olumludur. Bă̆ımlılı yaratması, zaman kaybı olması ve yüz yüze iletişimi zayıflatması açısından ise olumsuzdur."

Ö14: “Akıllı telefonlar sayesinde bilgiye ulaşma kolaylı̆̆ı ve hızı artmıştır. Yine akıllı telefonlar sayesinde alışveriş yapabilme, fatura ödeyebilme, para transferi vb. pek çok uygulama işimizi kolaylaştırmaktadır. Fakat tüm bunlara ek olarak sosyal medya kullanımının artmasıyla toplumun telefona olan ilgisi bağımlilık haline gelmiş ve bu durum bireyleri ve toplumu derinden etkilemiştir. Toplum kültürel yozlaşma içine girmektedir. Sosyal medya kullanımı olumlu ve olumsuz her olayı, bilgiyi hızlıca yatmaktadır. Olumsuz olaylar toplumu kötü yönde etkilemektedir."

Tablo 18. Türkçe Öğretmeni Adaylarının Akıllı Telefon Uygulamasının Avantaj ve Dezavantajlarına Yönelik Görüşleri

\begin{tabular}{llll}
\hline \multicolumn{1}{c}{ Akıllı Telefon Uygulaması } & f & \multicolumn{1}{c}{ Akıllı Telefon Uygulaması } & f \\
\hline Avantajları & 6 & Dezavantajları & 4 \\
Bilgiye kolay ulaşma & 5 & Zaman kaybı & 2 \\
Zamanı verimli kullanmayı sağlama & 3 & Bağımlılık yaratması & 2 \\
İletişim kolaylığı sağlama & 3 & Tembelliğe alıştırma & 1 \\
Erişilebilirlik & 3 & Dikkat dağınıklı̆ı yaratma & 1 \\
Kullanışlılığının olması & 2 & & \\
Çağa ayak uydurması & 1 & \\
Bazı konulara dikkat çekme & 1 & \\
Hem avantaj hem de dezavantajdır & 6 & \\
\hline
\end{tabular}


Türkçe öğretmeni adaylarının 6'sı akıllı telefon uygulamasının avantajları olduğunu ifade ederken; 4'ü ise akıllı telefon uygulamasının dezavantajları olduğunu ifade etmektedir. Türkçe öğretmen adaylarının 6'sı ise akıllı telefon uygulamasının hem avantajlarının hem de dezavantajlarının olduğunu ifade etmektedirler. Türkçe öğretmeni adayları bilgiye kolay ulaşılabilirliğinden $(n=5)$, zamanı verimli kullanmaya yardımcı olduğundan $(n=3)$, iletişim kolaylığı sağlamasından $(n=3)$, erişilebilirlikten $(n=3)$, kullanışlı olmasından $(n=2)$, çağa ayak uydurma noktasından $(n=1)$ ve bazı noktalara dikkat çekmesinden $(n=1)$ dolayı akıllı telefonun avantajlı olduğunu ifade etmektedir. Zaman kaybına sebep olmasından $(n=2)$, bağımlılığa sebep olmasından $(n=2)$, kişiyi tembelliğe alıştırmasından $(n=1)$ ve dikkat dağınıklığı ortaya çıkarmasından $(n=1)$ dolayı akıllı telefonun dezavantajlarını olduğunu düşünen öğretmen adayları da bulunmaktadır.

Ö2: "Hem avantaj hem de dezavantaj olduğunu düşünüyorum. İnsanlar bir bilgiye ulaşmaya çalıştıklarında kolayca çok vakit kaybetmeden ulaşabiliyorlar fakat dezavantaj kısmı ise bunları yaparken kütüphaneleri göz ardı ediyorlar kütüphaneleri unutuyorlar bir şeyler çabalamadan birçok bilgiye ulaşıyorlar bu da onları tembelliğe ittiğini düşünüyorum."

Ö6: "Bu, yerine göre değişebilir. Evde günde 1-2 saat akıllı telefonla vakit geçirilmesi kötü bir durum değildir. Aksine bilgiye ulaşma, iletişim kurma açısından avantajlı bir durumdur ancak sürekli telefonla ilgilenilmesi, okula telefon götürülmesi, sürekli oyun oynanması çocuklarm gelişime zarar vereceği için dezavantajlı durumlardır."

Ö11: "Avantajdır. Günümüzde her şeyimizi akıllı telefon sayesinde kolaylıkla ulaşabiliyoruz. Ve cebimizde vs. kolaylikla taşınabiliyor."

Ö14: "Çağın şartları gereğgi öğrencilerin akıllı telefonlarının olması birer avantajdır. Bilgilere ulaşma hızı, e kütüphanelerden kitap okuyabilme, teknolojiyi kullanabilmeyi öğrenme, öğretmenleri ve sinıf arkadaşlar ile iletişim halinde olabilmeleri için bunlar olumlu birer özelliktir. Fakat akıllı telefon kullanımı öğrencilerde bağımlılı̆̆a dönüşmeden önce önlem alınarak kullanımı sinırlandırılmalıdır. Öğrenci daha sonraki hayatında da bu sinirlandırmalara uyacaktır."

Ö16: “Avantaj. Çünkü dikkatlerini çekiyor, eğitim materyallerinin akıllı telefona uyarlanması öğrenciler için her faydalı olurdu. Ayrıca akıllı telefon artık internet kadar yaygin ve gerekli bir alet, eksikliği zararlı bile olabilir."

Tablo 19. Türkçe Öğretmeni Adaylarının Kullandıkları Akıllı Telefon Uygulamaları

\begin{tabular}{ll}
\hline Akıllı Telefon Uygulamaları & $\mathbf{f}$ \\
\hline Web sitesini ziyaret etme & 9 \\
Sosyal ağlardan mesaj gönderme & 8 \\
Fotoğraf ve video çekebilme & 7 \\
İnternette arama yapma & 6 \\
Görüntülü görüşme yapma & 6 \\
Fotoğraf ve video gönderebilme & 3 \\
Ekran görüntüsü alma & 3 \\
Ses kaydı yapma & 2 \\
\hline
\end{tabular}


Takvim girdisi oluşturma 1

E-posta yollama

Navigasyon

Hepsi

Türkçe öğretmeni adayları akıllı telefonlarındaki uygulamalardan web sitesini ziyaret etme $(n=9)$, sosyal ağlardan mesaj gönderme $(n=8)$, fotoğraf ve video çekebilme $(n=7)$, internette arama yapma $(n=6)$, görüntülü görüşme yapma $(n=6)$, fotoğraf ve video gönderebilme $(n=3)$, ekran görüntüsü alma $(n=3)$, ses kaydı yapma $(n=1)$, takvim girdisi oluşturma $(n=1)$, e-posta yollama $(n=1)$ ve navigasyonu $(n=1)$ kullanmaktadır. Öğretmen adaylarından 2'si ise bütün uygulamaları (web sitesini ziyaret etme, e-posta yollama, fotoğraf ve video çekebilme, sosyal ağlardan mesaj gönderme, ses kaydı yapma, navigasyon, internette arama yapma, kablosuz ağlara bağlanma, ekran görüntüsünü alma, resimleri kırpma ve yeniden boyutlandırma, sosyal ağ uygulamaları üzerinden görüntülü görüşme yapma, takvim girdisi oluşturma) kullandıklarını ifade etmiştir.

Ö4: "Akıllı telefon uygulamalarından en çok kullanım stralamam şöyledir: fotoğraf ve video çekebilme, sosyal ağlardan mesaj gönderme, internette arama yapma, e-posta yollama, web sitesini ziyaret etme, sosyal ăg uygulamalar üzerinden görüntülü görüşme yapma, navigasyon."

Ö7: "Sosyal ă̆ uygulamaları üzerinden görüntülü konuşmaya çok zaman ayırdığımı söyleyebilirim."

Ö10: "Sosyal ă̆lardan mesaj gönderme ve fotoğraf çekmeyi çok fazla kullanıyorum. Daha çok twitterdan girip gündemi takip ediyorum. Ĕ̆lenceli videoları arkadaşlarımla paylaşıyorum."

Ö11: "En çok mesaj yollama ve sosyal medyayı kullanıyorum. Bunlardan sonra da google a merak ettiğim şeyleri yazıp değişik sitelerden merakımı gidermeye çalışıyorum."

Ö12: “Günlük e postalarım kontrol ediyorum. Gerekli durumda Web sitesinden araştırma yapıyorum. Fotoğraf çekmeyi seviyorum. Günlük sosyal ă̆lardan mesajlaşıyorum. Ekran görüntüsü almanın kolaylık sağladığıı düşünüyorum."

Ö14: “Aslında akıllı telefon uygulamalarının pek çŏ̆unu kullanıyorum. Bu karantina günlerinde sosyal ă̆ uygulamaları üzerinden görüntülü konuşma özelliği ile uzaktaki akraba ve arkadaşlarımla konuşup iletişim kurabiliyorum. Yine sosyal ağlardan mesaj göndererek haberleşme ihtiyacımı karşılıyorum. Internette arama yaparak merak ettiğim bilgilere ulaşabiliyorum. Ekran görüntüsü alarak bilgileri saklayabiliyorum. Fotoğraf ve video çekmese akıllı telefonumu kullanıyorum."

Ö15: "En çok kullandığım sosyal hesaplardan haberleşme oluyor. Instagram ve Whatsapp. Instagramı fotoğraf veya video yüklemek niyetine kullanmam kendim çok fazla fotoğraf çekinmeyi sevmem kamera, video çok fazla kullanmam. Oradan hikâyeler izlerim ve sayfalar gezerim. Whatsapp ise arkadaşlarımla her daim konuşurum. Diğer en fazla kullandığım şey de web aramadır. Aklıma takılan her şeyi hemen arar bakarım. En basit bir şey bile olsa girerim."

Ö16: "Sosyal medya, zaman takibi, e-mail kontrolü, öğrenci ve iş takibi (uygulama üzerinden), görüntülü aramalar, internette araştırma yapma vs." 
Tablo 20. Türkçe Öğretmeni Adaylarının ‘Kişinin Akıllı Telefon Ekranına Bakıp, Karşısındaki Kişiyi Hiç Umursamamasının Bir Elektronik Hastalık Olduğunu’ Bilip Bilmeme Durumlar1

Elektronik Hastalık Olduğunu $\mathrm{f}$

Evet, biliyorum 9

Hayır, bilmiyorum 3

Türkçe öğretmeni adaylarından 'Kişinin akıllı telefon ekranına bakıp, karşısındaki kişiyi umursamamasının bir elektronik rahatsızlık olduğunu' 9'u bilmekte, 3'ü ise bilmemektedir.

Tablo 21. Türkçe Öğretmeni Adaylarının Kişinin Akıllı Telefon Ekranına Bakıp Karşısındaki Kişiyi Hiç Umursamamasının Meydana Getirdiği Elektronik Rahatsızlığın Kendisinde veya Çevresinde Görülüp Görülmeme Durumları

\begin{tabular}{ll}
\hline Kendisinde veya Çevresinde Görülüp Görülmeme Durumu & f \\
\hline Bu akıllı telefon rahatsızlığı bende var & 4 \\
Bu akıllı telefon rahatsızlığı çevremde var & 6 \\
Bu akıllı telefon rahatsızlığı çevremde yok & 2
\end{tabular}

Türkçe öğretmeni adaylarından 4'ü 'kişinin akıllı telefon ekranına bakıp, karşısındaki kişiyi hiç umursamamasının meydana getirdiği elektronik rahatsızlı̆̆ın' kendisinde olduğunu düşünmektedir. Adaylardan 6'sı bu rahatsızlığın çevresindeki kişilerde bulunduğunu, 2'si ise bu rahatsızlığın çevresindeki kişilerde olmadığını ifade etmektedir.

Tablo 22. Türkçe Öğretmeni Adaylarının Kişinin Akıllı Telefon Ekranına Bakıp Karşısındaki Kişiyi Hiç Umursamamasının Meydana Getirdiği Elektronik Rahatsızlığın Tedavisine Yönelik Görüşleri

\begin{tabular}{ll}
\hline Rahatsızlığın Tedavisine Yönelik Görüşler & f \\
\hline Kendi durumunun farkında olması & 5 \\
Akıllı telefonu ölçülü kullanmak & 3 \\
Bilinçlenmek ve bilinçlendirmek & 2 \\
Akıllı telefon kullanımın azaltılması & 2 \\
Profesyonel bir yardım almak & 1 \\
İletişim kurmayı arttırmak & 1 \\
Sosyalleşmenin arttırılması & 1 \\
İhmalkârlı̆̆ı önlemek & 1 \\
\hline
\end{tabular}

Türkçe öğretmeni adaylarının kişinin akıllı telefon ekranına bakıp karşısındaki kişiyi hiç umursamamasının meydana getirdiği elektronik rahatsızlı̆̆ın tedavisine yönelik görüşleri; kişinin kendi durumunun farkında olması $(n=5)$, akıllı telefonu ölçülü kullanması $(n=3)$, bu konuda bilinçlenmek ve bilinçlendirmek $(n=2)$, akıllı telefon kullanımının azaltılması $(n=2)$, profesyonel bir yardım alınması gerektiği $(n=1)$, çevreyle iletişim kurulmasının arttırılması $(n=1)$, sosyalleşmenin artırılması $(n=1)$ ve bu konuda ihmalkârlığın önlenmesi $(n=1)$ şeklindedir. 
Ö1: "Evet biliyorum ve her geçen gün herkeste daha fazla meydana geldiğini düşünüyorum. Tedavisi daha fazla sosyalleşmeyi deneyerek."

Ö3: "Buna katılıyorum ve birçoğumuzda bunun olduğunu düşünüyorum. Birbirimizle daha sağhlklı ve etkili iletişim kurarsak telefona olan ihtiyacımızın ve bu sorunun ortadan kalkacağını düşünüyorum."

Ö4: "Evet, duymuştum. Çevremde bazı insanlarda bu durumu fark ettiğim oldu. Sanırım bunun için yakın zamanda psikologlara başvuranları da duymaya başlayacă̆ız. Sigara, alkol vb. bağgmlılığ gibi bunların da üst boyutta olanlarının profesyonel yardımla tedavi edilmeleri gerekecek. Iradesi kuvvetli olanlar kendi otokontrollerini devreye sokarak yapabilirler. Bunun için kendine sintrlamalar getirmeleri ve cep telefonundan mümkün olduğunca uzak durmalarn gerekir."

Ö5: "Hayır çevremde böyle bir durum yok. Bu hastah̆̆ğn tedavisi telefonu belli periyotlarla zamanı azaltarak kişiye kullandırılması yoluyla olabilir."

Ö6: "Bunun bir hastalık olduğgnu biliyorum. Bu hastalı̆̆ın kendimde de olduğunu düşünüyorum. Telefonla vakit geçirmeyi her gün biraz daha azaltarak bu hastahı̆ın azaltılabileceğini düşünüyorum."

Ö8: "Evet. Artık insanlar yaptıkları her işte arada bir telefona bakıyorlar ve buna engel olamıyorlar. Bu hastalık çevremde çok var. Tedavisi için insanlara eğitim verilmelidir ve insanlar önce bu yanlışın farkına varmalılar."

Ö13: "Yatmadan önce, sabah uyandiğımda ilk işim telefona bakmak. Günün belli zamanlarında da telefonla ilgileniyorum. Hastalık derecesinde olduğumu düşünmüyorum ama bağlllık var. Çevremde ise eskiden sadece telefonu gençler çok kullanıyor olarak tanımlanıyor ve eleştiri alıyorduk. Şimdi ise anne babamdan tutup çevreme baktığımda her yaştan insan hatta bebekler bile telefonla iç içe. Bu durumun düzelebileceğini düşünmüyorum. Sadece bilinçlenmek ve bilinçlendirmek gerektiğini düşünüyorum."

Ö14: "Evet bu telefon alışkanlı̆̆ı hastalık halini almaya iyice başlamaktadır. Sosyal medya ve internet kullanımı bireyleri akıllı telefonların sürekli kullanır, kontrol hale getirmiştir. Bu hastalığın çözümü akıllı telefon kullanımına sınır koymakla mümkün olabilir. Ölçülü kullanımı să̆lamak bu hastalı̆̆ı ortadan kaldıracaktır."

\section{Tartıșma, Sonuç ve Öneriler}

Araştırma sonucunda Türkçe öğretmeni adaylarının cinsiyet, yaş grupları, yaşamlarının çoğunu geçirdikleri yer, anne ve baba meslekleri, kardeş sayısı, ailenin ekonomik durumu, anne ve baba eğitim durumları, not ortalamaları, sınıf düzeyleri, sosyal medyada geçirilen süre, internette geçirilen süre ve düzenli gazete takip etme değişkenleri ile ölçeğin boyutları arasında istatistiksel olarak anlamlı bir farklılığın olmadığı görülmektedir. Kahyaoğlu, Akpınar, Baran, Akdoğan ve Aydoğdu (2016) akıllı cihazlara ve evde internet bağlantısına sahip öğrencilerin diğer öğrencilere göre webe özgü özyeterliklerinin anlamlı düzeyde yüksek çıktığını tespit etmiştir.

Araştırmanın sonucunda Türkçe öğretmeni adaylarının derslere katılım sağlamak, bir şeylerden haberdar olmak, iletişim kurmak, zaman geçirmek ve akıllı telefonların daha kullanışlı olması gibi nedenlerle uzaktan eğitim süresince akıllı telefonlarından yararlandıkları görülmüştür. Taylan'ın (2016) yaptığı araştırma sonucuna göre üniversite 
öğrencileri cep telefonlarını en çok mesajlaşma, sosyal medya ve konuşma amaciyla kullanırken; en az oyun, mail, araştırma, eğitim ve ödev amaçlı kullanmaktadır. Akıllı telefonlarla ilgili yapılan bu araştırmaya göre öğretmen adaylarının telefonlarını en çok derslere katılım sağlamak için kullandıkları görülmektedir. Bunun sebebi dünyada ve Türkiye'de görülen Covid-19 salgını sonucunda üniversitelerin uzaktan eğitim sürecini başlatması olabilir. Koşar'ın (2018) yaptığı çalışmada öğretmen adayları cep telefonunu genellikle iletişim amaçlı kullandıklarını belirtmektedirler. Öğretmen adayları, cep telefonlarını eğitim amaçlı da kullanmaktadırlar.

Yapılan birçok araştırmada akıllı telefon, sosyal medya ve internetin bireylerin hayatlarını kolaylaştırdığı görülmüştür (Hong, Chiu ve Huang, 2012; Bolton ve diğ., 2013, Yengin, 2016). Araştırmanın sonucunda akıllı telefonun hayatı kolaylaştırdığını düşünen Türkçe öğretmeni adayları bilgiye ulaşılabilirlik, iletişimi sağlama, tüm işlemlerin yapılabilmesi, ihtiyaçları giderebilme, duyurulardan haberdar olma, kendini daha rahat ifade etme, bilgiyi depolama ve sosyalleşmeyi sağlaması gibi nedenlerle böyle düşündüklerini belirtmişlerdir.

Bazı araştırmalar (Tang ve Lee, 2013; Boulianne, 2015; Eşitti, 2015; Öztürk, 2015) akıllı telefon, sosyal medya ve internetin bireylerin iletişim kurmasını olumsuz etkilediğini, bağımlılık yaratan uygulamalar olduğunu ve bireylerde psikolojik sorunlar oluşturduğunu belirtmektedir. Bu araştırmada akıllı telefonun hayatı kolaylaştırmadığını düşünen Türkçe öğretmeni adayları ise zamanı tükettiğinden, bağımlılık yaptığından ve monotonluğa sebep olduğundan dolayı böyle düşündüklerini ifade etmektedirler. Akıllı telefonu zaman kaybı olarak gören Türkçe öğretmeni adayları sosyal medyada geçirilen sürenin fazlalığından ve akıllı telefonun kişilerde bağımlılık yapmasından dolayı böyle düşünmektedirler. Akıllı telefonu zaman kaybı olarak görmeyen Türkçe öğretmeni adayları ise bilgiye kolay ulaşabildikleri, ekonomikliği sağlaması ve ihtiyaçları giderebilmesi nedeniyle böyle düşündüklerini ifade etmektedirler.

Araştırmanın sonucunda akıllı telefonun toplum üzerinde olumlu bir etkisinin olduğunu düşünen öğretmen adayları ihtiyaçları giderebildiğinden, bilgiye ulaşılabilirliğinden, erişilebilirlikten, iletişim kolaylığından, güncelliği sağlamasından ve kişisel gelişime yardımcı olmasından dolayı böyle düşündüklerini belirtmektedirler. Bulduklu ve Özer'in (2016) yaptığı araştırma sonucunda gençler akıllı telefonun olumlu etkilerini; bilgiye erişim, iletişimi kolaylaştırma, haberleşme, hayatı kolaylaştırma, mobilite ve erişim kolaylığı, zaman geçirme, sosyal ilişkiler, zaman kazanma, paylaşım şeklinde ifade etmektedirler.

Araştırmanın sonucunda Türkçe öğretmeni adayları akıllı telefonun toplum üzerindeki olumsuz etkisini asosyalliğe sebep olması, birtakım sağlık problemlerinin yaşanması, bilgi kirliliği meydana getirmesi, iletişim kopukluğuna sebep olması, zaman kaybı yaratması ve insanlarda bağımlılığa sebep olması şeklinde ifade etmektedirler. Bulduklu ve Özer'in (2016) yaptığı araştırma sonucunda gençler akıllı telefonun zararlarını; zaman kaybı, sağlık (baş ağrısı, radyasyon, vb.), bağımlılık, asosyallik, iletişimsizlik, dikkat dağınıklığı, tembellik, içeriksel denetimsizlik, ekonomik zarar, uykusuzluk ve ders çalışmayı engelleme şeklinde ifade etmektedirler. Koşar'ın (2018) yaptığı araştırmaya göre de öğretmen adayları kullandıkları cep telefonlarının zararlarını sağlık (dikkat dağınıklığı, baş ağrısı, göz yorgunluğu vb.), zaman (vakit kaybı), izolasyon (sohbet süresi, gerçeklikten soyutlanma, paylaşacaklarda azalma) ve içerik (tehlikeli web siteleri, dolandırıcılık, kötü niyetli kişiler) şeklinde ifade etmektedir. 
Araştırmanın sonucunda Türkçe öğretmeni adayları akıllı telefonun avantajlarını bilgiye kolay ulaşılabilirlik, zamanı verimli kullanma, iletişim kolaylığı sağlama, erişilebilirlik, kullanışlı olma, çağa ayak uydurma ve bazı noktalara dikkat çekme olarak belirtmektedir. Koşar'ın (2018) yaptığı çalışmada da öğretmen adayları cep telefon kullanmanın yararlarını iletişim, kişisel, eğitimsel ve sosyal konular şeklinde ifade etmektedir. Araştırmanın sonucunda Türkçe öğretmeni adayları, akıllı telefonun dezavantajlarını zaman kaybına sebep olması, bağımlılığa sebep olması, kişiyi tembelliğe alıştırması ve dikkat dağınıklığı şeklinde ifade etmektedirler. Koşar'ın (2018) yaptığı çalışmada öğretmen adayları cep telefonunun zararları konusunda en çok sağlığa verdiği zarara vurgu yapmışlar, bunun yanında başka sorunlar yarattğına da değinmişlerdir.

Araştırmanın sonucunda Türkçe öğretmeni adayları akıllı telefonlarından web sitesini ziyaret etme, e-posta yollama, fotoğraf ve video çekebilme, sosyal ağlardan mesaj gönderme, ses kaydı yapma, navigasyon, internette arama yapma, kablosuz ağlara bağlanma, ekran görüntüsünü alma, resimleri kırpma ve yeniden boyutlandırma, sosyal ağ uygulamaları üzerinden görüntülü görüşme yapma, takvim girdisi oluşturma uygulamalarını kullandıklarını ifade etmişlerdir. Koşar'ın (2018) yaptığı araştırmada öğretmen adayları değişen ihtiyaçları doğrultusunda telefonlarında çeşitli uygulamalar kullandıklarını belirtmişlerdir.

Akıllı telefonların günümüzde çok kullanılmasıyla beraber telefona bağlı gelişen rahatsızlıklar da artmıştır (Kaur ve Sharma, 2015; Pavithra ve Madhukumar, 2015; Gezgin, Çakır ve Yıldırım, 2016; Gupta, Garg, ve Arora, 2016). Birçok araştırmada (Szpakow, Stryzhak ve Prokopowicz, 2011; Singh, Gupta ve Garg, 2013; Kalaskar, 2015; Kaplan Akıllı, ve Gezgin, 2016) bireylerin akıllı telefonlarını sürekli kontrol ettiği ve bunun sonucunda bağımlılık oluştuğu belirtilmektedir. Nikhita, Jadhav ve Ajinkya (2015) ve Kalaskar (2015) araştırmalarında bireylerin sabah kalktında akıllı telefonlarını bulamadıklarında tedirginlik yaşadıklarını, akıllı telefona ulaştıktan sonra ilk olarak sosyal medya hesaplarına giriş yaptıklarını belirlemişlerdir. Araştırmanın sonucunda Türkçe öğretmeni adayları akıllı telefonları çok kullanmaktan dolayı rahatsızlık yaşadıklarını belirtmektedirler. Türkçe öğretmeni adayları, kişinin kendi durumunun farkında olması, akıllı telefonu ölçülü kullanması, bu konuda bilinçlenmek ve bilinçlendirmek, akıllı telefon kullanımının azaltılması, profesyonel bir yardım alınması gerektiği, çevreyle iletişim kurulmasının arttırılması, sosyalleşmenin artırılması ve bu konuda ihmalkârlığın önlenmesi halinde akıllı telefon rahatsızlıklarının ortadan kalkabileceğini belirtmişlerdir. Yılmaz (2013) yaptığ1 çalışma sonucunda phubbingin günümüz şartlarında insanlar arasında bağımlılık haline gelmeye başlayan bir hastalık olduğunu, phubbing ile mücadele etmek amacıyla birtakım girişimler olduğunu belirtmektedir. Sonuç olarak öğretmen adaylarının akıllı telefon kullanma konusunda özyeterli olmalarına rağmen, aşırı kullandıkları için de bağımlı durumunda oldukları görülmektedir.

\section{Öneriler}

- Türkçe eğitimiyle ilgili akıllı telefon uygulamalarına yönelik içerikler zenginleştirilmeli

- Akıllı telefonun eğitim için kullanaılmasına yönelik deneysel uygulamalar yapılmalı

- Öğretmen adaylarının akıllı telefon bağımlık düzeyleri derinlemesine incelenip, bu sorunla ilgili somut çözüm önerileri geliştirilmeli 


\section{Kaynakça}

Aksakallı, A. (2019). Eleştirel pedagojiye yönelik öğretmenlerin eğitim inançları. Egitimde Nitel Araştırmalar Dergisi - Journal of Qualitative Research in Education, 7(2), 583- 605. doi: 10.14689/issn.2148-2624.1.7c.2s.6m

Aktay, S. (2018). A Validity and Reliability Study of the Smartphone Self-Efficacy Scale. International Technology and Education Journal, 2(2), 11-18.

Alkan, V., Şimşek, S. ve Armağan Erbil, B. (2019). Karma yöntem: Öyküleyici alanyazın incelemesi. Eğitimde Nitel Araştırmalar Dergisi, 7(2), 558-581. doi: 10.14689/issn.21482624.1.7c.2s.5m

Bahar, H. H. (2019). Sınıf öğretmen adaylarında akademik öz-yeterlik algısının akademik başarıyı yordama gücü. İlköğretim Online, 18(1): s. 149-157. doi: 10.17051/ilkonline.2019.527178

Bandura. A. (1986). Social foundations of thought and action: A social cognitive theory. New Jersey: Prentice Halı.

Bolton, R.N., Parasuraman, A., Hoefnagels, A., Migchels, N., Kabadayi, S., Gruber, T., Komarova Loureiro, Y. \& Solnet, D. (2013) Understanding generation Y and their use of social media: A review and research agenda. Journal of Service Management, 24(3), pp. 245267. doi: $10.1108 / 09564231311326987$.

Boulianne, S. (2015). Social media use and participation: A meta-analysis of current research. Information. Communication ve Society, 18(5), 524-538. https://doi.org/10.1080/1369118X.2015.1008542

Bulduklu, Y. ve Özer, N.P. (2016). Gençlerin akıllı telefon kullanım motivasyonları. İnsan ve Toplum Bilimleri Araştırmaları Dergisi. 5(8), s. 2963-2986. DOI: 10.15869/itobiad.265374

Creswell, J. W. ve Plano Clark, V. L. (2007). Designing and conducting mixed methods research (1.Bask1). London: Sage Publications Ltd.

Dembo, M. H. (2004). Motivation and learning strategies for college success: A self-management approach (2nd ed.). Mahwah, NJ: Erlbaum

Donald. M. G. (2003). Handbook of self and identity. Guildford Press.

Elhai, J. D., Levine, J. C., ve Hall, B. J. (2019). The relationship between anxiety symptom severity and problematic smartphone use: A review of the literature and conceptual frameworks. Journal of Anxiety Disorders, 62, 45-52. doi: 10.1016/j.janxdis.2018.11.005

Eşitti, Ş. (2015). Bilgi çağında problemli internet kullanımı ve enformasyon obezitesi: Problemli internet kullanımı ölçeğinin üniversite öğrencilerine uygulanması. İstanbul Üniversitesi İletişim Fakültesi Dergisi, 49, 75-97. Retrieved from https://dergipark.org.tr/tr/pub/iuifd/issue/22900/245174. Erişim Tarihi: 15.04.2020

Gelen, B., Akçay, B., Tiryaki, A., \& Benek, İ. (2019). Fen bilimleri öğretmen adaylarının Fenteknoloji mühendislik-matematik (FeTeMM)'e yönelik özyeterlik ölçeği: Türkçe'ye uyarlama, geçerlik ve güvenirlik çalışması. Eğitimde Kuram ve Uygulama, 15(1), 88-107. doi: 10.17244/eku.395204 
Gezgin, D. M., Çakır, Ö. ve Yıldırım S. (2016). Ergenler arasında nomofobi yaygınlık düzeyi ile internet bağımlılığının ilişkisi. 3.Uluslararası Avrasya Eğitim Araştırmaları Kongresi, Muğla-Turkey.

Gupta, N., Garg, S. and Arora, K. (2016). Pattern of mobile phone usage and its effects on psychological health, sleep, and academic performance in students of a medical university. National Journal of Physiology, Pharmacy and Pharmacology, 6(2), 132-139. doi: 10.5455/njppp.2016.6.0311201599

Hong, F. Y., Chiu, S. I. and Huang, D. H. (2012). A model of the relationship between psychological characteristics, mobile phone addiction and use of mobile phones by Taiwanese university female students. Computers in Human Behavior, 28(6), 2152-2159. https://doi.org/10.1016/j.chb.2012.06.020

Hayırcı, B. (2019). Lise öğrencilerinin akıllı telefon bağımlılık düzeyleri ile sosyal kaygı ve yalnızlık düzeyleri arasındaki ilişkinin incelenmesi (Yayımlanmamış Yüksek Lisans Tezi). Ordu Üniversitesi Sosyal Bilimler Enstitüsü Rehberlik Ve Psikolojik Danışmanlık Anabilim Dalı.

Kahyaoğlu, Y., Akpınar, E., Baran, B., Akdoğan, F. S. Ve Aydoğdu, B. (2016). Pedagojik formasyon programı öğrencilerinin webe özgü öz-yeterlik algılarının incelenmesi. Journal of Instructional Technologies $\mathcal{E}$ Teacher Education, 5(3),118-126. http://static.dergipark.org.tr/article-download/cc61/8864/4331/58a1abe53b0aa.pdf?

Kalaskar, P. B. (2015). A study of awareness of development of NoMoPhobia condition in smartphone user management students in Pune city. ASM's International E-Journal on Ongoing Research in Management and IT, 10, p. 320-326.

Kaplan Akıllı, G. ve Gezgin, D. M. (2016). Üniversite öğrencilerinin nomofobi düzeyleri ile farklı davranış örüntülerinin arasındaki ilişkilerin incelenmesi. Mehmet Akif Ersoy Üniversitesi Ĕ̆itim Fakültesi Dergisi, 40, s. 51-69. DOI: 10.21764/efd.80423

Karadağ E, Tosuntaş Ş. B., Erzen E., Duru, P., Bostan, N., Mizrak Şahin, B. and Babadağ B. (2015) Determinants of phubbing, which is the sum of many virtual addictions: A structural equation model. Journal of Behavioral Addictions, 4(2), p. 60-74. DOI: 10.1556/2006.4.2015.005

Karadağ E, Tosuntaş Ş. B., Erzen E., Duru, P., Bostan, N., Mizrak Şahin, B., Çulha, İ. ve Babadağ, B. (2016). Sanal dünyanın kronolojik bağımlılı̆̆ı: Sosyotelizm (phubbing). Addicta: The Turkish Journal on Addiction, 3, 223-269. http://dx.doi.org/10.15805/addicta.2016.3.0013

Kartol, A. ve Peker, A. (2020). Ergenlerde sosyal ortamlarda gelişmeleri kaçırma korkusu (fomo) yordayıcılarının incelenmesi. OPUS- Uluslararası Toplum Araştırmaları Dergisi, 15(21), 454-474. DOI: 10.26466/opus.628081

Kaur, A. and Sharma, P. (2015). A Descriptive Study to Assess the Risk of Developing Nomophobia among Students of Selected Nursing Colleges Ludhiana, Punjab. International Journal of Psychiatric Nursing, 1(2), 1-6. DOI: 10.5958/2395-180X.2015.00051.1

Koşar, D. (2018). Öğretmen adaylarının cep telefonu kullanımına ilişkin görüşlerinin incelenmesi. Uluslararası Sosyal Araştırmalar Dergisi, 11(55). DOI: 10.17719/jisr20185537236 
Koçak Macun, B., Macun, B. ve Safalı, S. (2019). Öğretmen adaylarının öğretmen özyeterlik inanç düzeyleri ile iş hayatına hazırbulunuşluklarının incelenmesi. Uluslararası Türkçe Edebiyat Kültür Ĕ̆itim Dergisi, 8(1), 549-567.

Kuyucu, M. (2017). Gençlerde Akıllı telefon kullanımı ve akıllı telefon bağımlılığı sorunsalı: "Akıllı telefon(kolik)" üniversite gençliği. Global Media Journal TR Edition, 7(14). 328-359

National Research Council. (2012). Education for life and work: Developing transferable knowledge and skills in the 21st century. Committee on defining deeper learning and 21st century skills. (J. W. Pellegrino and M. L. Hilton, Eds). Board on Testing and Assessment and Board on Science Education, Division of Behavioral and Social Sciences and Education. Washington, DC: The National Academies Press. Retrieved Form https://hewlett.org/wpcontent/uploads/2016/08/Education_for_Life_and_Work.pdf Date: 02.04.2020

Nazir T. and Pişkin M. (2016) Phubbing: A technological invasion which connected the world but disconnected humans. The International Journal of Indian Psychology 3(4), 2349-3429. DOI: $10.25215 / 0403$

Nikhita, C. S., Jadhav, P. R. and Ajinkya, S. A. (2015). Prevalence of mobile phone dependence in secondary school adolescents. Journal of clinical and diagnostic research, 9(11), VC06-VC09. doi: 10.7860/JCDR/2015/14396.6803

Özteke Kozan, H. İ., Kavaklı, M., Ak, M. ve Kesici, Ş. (2019). Akıllı telefon bağımlılığı, genel aidiyet ve mutluluk arasındaki ilişkilerin yapısal eşitlik modellemesi ile incelenmesi. Klinik Psikiyatri Dergisi, 22(4), 436-444. DOI: 10.5505/kpd.2019.87587

Öztürk, U. C. (2015). Bağlantıda kalmak ya da kalmamak işte tüm korku bu: internetsiz kalma korkusu ve örgütsel yansımaları. Uluslararası Sosyal Araştırmalar Dergisi, 8(37), s. 629-638. DOI: 10.17719/jisr.20153710629

Pajares, F. (2003). Self-efficacy beliefs, motivation, and achievement in writing: A review of the literature. Reading and Writing Quarterly, 19(2), 139-158. https://doi.org/10.1080/10573560308222

Pajares, F. and Schunk, D. H. (2001). Self-beliefs and school success: Self-efficacy, selfconcept, and school achievement. In R. Riding ve S. Rayner (Eds.), Selfperception (pp. 239266). London: Ablex Publishing.

Pavithra, M. B. \& Madhukumar, S. (2015). A Study on Nomophobia-Mobile Phone Dependence, Among Students of a Medical College in Bangalore. National Journal of Community Medicine, 6(3), 340-344.

Polat, R. (2017). Dijital hastalık olarak nomofobi. Yeni Medya Elektronik Dergi. 1(2).164-172. Retrieved from https://dergipark.org.tr/tr/pub/ejnm/issue/34698/383554

Recepoğlu, S., \& Recepoğlu, E. (2019). Öğretmen adaylarının özyeterlik algıları ile öğretmenlik mesleğine yönelik motivasyonları arasındaki ilişki. Hacettepe Üniversitesi Eğitim Fakültesi Dergisi. Advance online publication. doi: 10.16986/HUJE.2019053943

Selçuk, G. ve Hursen, Ç. (2016). The Examination of Instructors' Views on the Principles of Critical Pedagogy. Croatian Journal of Education, 18(4), 1121-1140. doi: 10.15516/cje.v18i4.1811 
Snyder, C. R. and Lopez, S. (2002). Handbook of positive psychology. Oxford: Oxford University Press.

Singh, B., Gupta, R. and Garg, R. (2013). Mobile Phones; A Boon or Bane for Mankind?Behavior of Medical Students. International Journal of Innovative Research and Development, 2(4), 196-205. http://internationaljournalcorner.com/index.php/ijird_ojs/article/view/133303/92510

Szpakow, A., Stryzhak, A. and Prokopowicz, W. (2011). Evaluation of threat of mobile phone - addition among Belarusian University students. Progress in Health Sciences, 1(2), 96- 101.

Şimşek, K. ve Zabun, B. (2019). Türkiye'de ortaöğretim öğrencilerinin akıllı telefon bağımlılığı: kahramanmaraş örneği. Journal Of Social, Humanities and Administrative Sciences, 5(16): 547-559. : http://dx.doi.org/10.31589/JOSHAS.140

Tang, G. and Lee, F. L. F. (2013). Facebook use and political participation: The impact of exposure to shared political information, connections with public political actors, and network structural heterogeneity. Social Science Computer Review, 31(6), 763-773. doi:10.1177/0894439313490625

Taylan, H. H. (2016). Yükseköğretim öğrencilerinde akıllı telefon bağımlılığı. Uluslararası Yükseköğretimde Kalite Kongresi. 24-25 Kasım, Sakarya.

Ünal, A. Ö. ve Şahin, M. (2013). Lise öğrencilerinin yaşam doyumlarının bazı değişkenlere göre yordanması. Cumhuriyet International Journal of Education, 2(3), 46-63. https://arastirmax.com/en/system/files/1066/2101-12893-2-pb.pdf. Erişim Tarihi: 20.04.2020

Yam, F. C. ve İlhan, T. (2020). Modern çağın bütünsel teknolojik bağımlılı̆̆ı: Phubbing. Psikiyatride Güncel Yaklaşımlar, 12(1), s. 1-15. https://doi.org/10.18863/pgy.551299

Yalçın, S. (2018). 21. yüzyıl becerileri ve bu becerilerin ölçülmesinde kullanılan araçlar ve yaklaşımlar. Ankara Üniversitesi Ĕ̆itim Bilimleri Fakültesi Dergisi, 51(1), 183-201. DOI: 10.30964/auebfd.405860

Yengin, D. A. (2016). Sosyal Medya Ve Akıllı Mobil Teknoloji: Akıllı Sosyal Yaşamlar. The Turkish Online Journal of Design, Art and Communication (TOJDAC), 6(2), 105-113. http://tojdac.org/tojdac/VOLUME6-ISSUE2_files/tojdac_v06i2104.pdf Erişim Tarihi: 20.04.2020

Yılmaz, E. O. (2013). Phubbing nedir? dijital çă̆ hastalığı üzerine kısa bir not. https://www.academia.edu/5096961/Phubbing Nedir Dijital \%C3\%87a\%C4\%9F Hastal\% C4\%B1\%C4\%9F\%C4\%B1 \%C3\%9Czerine K\%C4\%B1sa Bir Not. Erişim Tarihi: 21.04.2020 